\title{
INEQUITABLE DISTRIBUTION OF HEALTH RESOURCES IN BRAZIL: AN ANALYSIS OF NATIONAL PRIORITY SETTING
}

\author{
Fabio Ferri-de-Barros*, Andrew W. Howard**, Douglas K. Martin***
}

\begin{abstract}
The purpose of this paper is to describe the national priority setting process for the public health system in Brazil, evaluating the process using the ethical framework Accountability for Reasonableness, and equity considerations highlighted in the 2008 WHO Commission on Social Determinants of Health. We searched the Brazilian Ministry of Health website for documents that described priority setting within the Brazilian Universal Health Care System (SUS). The National Health Conference (CNS) has been defined by the Ministry of Health as the democratic priority setting forum for SUS. The most recent such conference $\left(13^{\text {th }}\right.$ CNS, 2007) is the subject of this paper.

Our analysis suggests that the process of priority setting within SUS has not yet achieved the ethical standards of legitimacy and fairness, and that inequitable distribution of decision making power under- represents users in poor areas. The unmet need for hospital care for children in Brazil, which reflects a remarkable inequality of opportunity for human development, may be a product of poor priority setting processes and inequity in representation.
\end{abstract}

Key words: priority setting, public health, inequitable distribution

\section{DISTRIBUCIÓN INJUSTA DE LOS RECURSOS EN SALUD EN BRASIL: UN ANÁLISIS DEL ESTABLECIMIENTO DE PRIORIDADES NACIONALES}

Resumen: Este artículo pretende describir el establecimiento de prioridades nacionales en el proceso de cuidado del sistema de salud en Brasil, evaluando el proceso con el empleo del marco ético de Administración Razonable, y de consideraciones de equidad destacadas por la Comisión sobre Determinantes Sociales de la Salud de la Organización Mundial de la Salud (OMS). Buscamos documentos que describieran el establecimiento de prioridades dentro del Sistema Único de Salud brasileño (SUS) en el sitio del Ministerio de Salud Brasileño. La Conferencia Nacional sobre Salud (CNS) ha sido definida por el Ministerio de Salud como el foro del SUS para el establecimiento de prioridades democráticas. La 13a CNS, 2007 -la más reciente de dichas conferenciasconstituye el tema de este artículo.

Nuestro análisis sugiere que el proceso de establecimiento de prioridades dentro del SUS no ha alcanzado aún los patrones éticos de legitimidad y justicia, y que la distribución injusta de las instancias de poder de decisión no representa realmente a las áreas más pobres. La meta aún no alcanzada de necesidad de hospitales para nińos en Brasil significa una notable falta de igualdad en las oportunidades para el desarrollo humano y puede que sea producto de la mala definición del proceso de prioridades y de la falta de equidad en la representación.

Palabras clave: establecimiento de prioridades, salud pública, distribución injusta

\section{DISTRIBUIÇÃO INJUSTA DOS RECURSOS EM SAÚDE NO BRASIL: UMA ANÁLISE DA DEFINIÇÃO DE PRIORIDADES NACIONAIS}

\begin{abstract}
Resumo: Este artigo pretende descrever a definição de prioridades nacionais no processo de cuidado do sistema de saúde no Brasil, avaliando o processo com o emprego do marco ético de Administração Razoável e de consideraçóes sobre a equidade, destacadas pela Comissão sobre Determinantes Sociais da Saúde da Organização Mundial da Saúde (OMS). Buscamos documentos que descreveram o estabelecimento de prioridades dentro do Sistema UUnico de Saúde brasileiro (SUS) no site do Ministério da Saúde brasileiro na web. A Conferência Nacional de Saúde (CNS) foi definida pelo Ministério da Saúde como o fórum do SUS para o estabelecimento de prioridades democráticas. A 13a CNS, 2007 -a mais recente das citadas conferências- constitui o tema deste artigo.

Nossa análise sugere que o processo de estabelecimento de prioridades dentro do SUS não alcançou ainda os padrôes éticos de legitimidade e justiça e que a distribuição injusta das instâncias do poder de decisão não alcança realmente as áreas mais pobres. A meta ainda não alcançada da necessidade de hospitais infantis no Brasil, o que significa uma notável falta de igualdade de oportunidades para o desenvolvimento humano e pode ser produto de uma má definiçáo do processo de prioridades e da falta de equidade na representaçáo.
\end{abstract}

Palavras-chave: definição de prioridades, saúde pública, distribuição injusta.

* Clinical fellow The Hospital for Sick Children. PhD student, Institute of Medical Sciences, University of Toronto. Canada

** Director, Office of International Surgery. Medical Director, Trauma Program, Associate Professor, Departments of Surgery and Health Policy, Management, and Evaluation, University of Toronto. Canada

*** Associate Professor Department of Health Policy, Management and Evaluation and the Joint Centre for Bioethics, University of Toronto, Canada Correspondence: douglas.martin@utoronto.ca 


\section{Introduction}

The 2008 World Health Organization (WHO) Commission on Social Determinants of Health recommended promoting health equity through actions on the social determinants of health(1). Brazil was a partner on that commission, and the federal government has been proactive to address social inequities. National policies such as Bolsa Familia, the largest conditional cash transfer program in the world, received special recognition for equalizing income distribution(2). Bolsa Familia was meant to improve access to primary education and health care for the poorest families. In addition, the Family Health Program (PSF) developed by the federal government, during the last 18 years, has led to remarkable improvements on health indicators across the emerging Brazilian nation(1).

Despite improvements in primary health care, the Brazilian Universal Health Care System (SUS) currently faces challenges in delivering universal and equitable health care to 190 million Brazilians(3). Allocation decisions and planning occur at National Health Conferences held every four years in accordance with federal law 8.142. The most recent one $\left(13^{\text {th }} \mathrm{CNS}\right.$, $2007)$ is the subject of this paper.

The ethics framework Accountability for Reasonableness (A4R)(4) outlines the conditions that decision makers must fulfil to ensure legitimate and fair priority setting. A4R has been recognized as a significant advance in studying priority setting in health services research(5). Developed in the context of managed care reform in the United States, the framework has been validated in the Canadian [public] health system(6) and in several other countries(4).

The purpose of this paper is to describe the priority setting process for the public health system in Brazil, and evaluate it using the conditions of A4R and the equity considerations highlighted in the $2008 \mathrm{WHO}$ Commission.

Methods We have searched the Brazilian Ministry of Health website www.saude.gov.br for documents that described priority setting within SUS. The CNS has been defined, by the Ministry of Health, as the democratic priority setting forum for SUS. The $13^{\text {th }}$ CNS was held in 2007 with the following objectives:

Evaluate the status quo of health in Brazil according to the SUS framework;
Define the guidelines to ensure health as a fundamental human right and State policy;

Define the guidelines to enable strengthened social participation to ensure full implementation of SUS.

Shortly after the $13^{\text {th }}$ CNS the Ministry of Health published the four-year plan for allocating $\mathrm{R} \$ 89.4$ billion for 73 measures and 165 goals for SUS. The legal document that has set the rules for the $13^{\text {th }} \mathrm{CNS}$, as well as the document Mais Saude: Direito de Todos, the four-year (2008-2011) priority setting plan for SUS, were analyzed using the four conditions of A4R (see Box 1)(7). Equity concerns were addressed by considering decision making power of users of the system as recommended by the 2008 WHO commission(1).

Box 1: The Four Conditions of A4R(7)

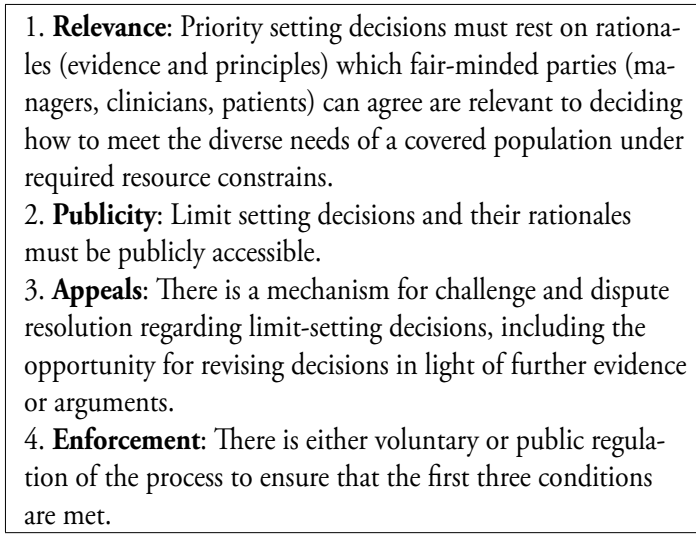

\section{Results}

\section{The priority setting context}

The $13^{\text {th }}$ CNS occurred in all jurisdictional levels in three distinct phases: Municipal, State and Federal, through the following process: each jurisdictional health council was required to elect an ad hoc committee and produce a priority setting report for health policies concerning a core subject pre-determined by the CNS committee. In 2007 the theme was "Health and Quality of Life: State Policies and Development", which was broken down in 3 sub-themes:

1. Challenges to ensure health as a human right in the XXI century: State, Society and Development Patterns.

2. Public health policies and quality of life: (the role of) SUS in Social Security and the "Pacto pela Saude" (Pact for Health). 
3. Societal participation in the accomplishment of health as a human right.

Each sub-theme was to be discussed, according to pre-determined scripts, in a round table format. The municipal reports were sent to the State committee and the State reports, along with the Federal District report, were sent to the ad hoc national committee. Ten discussion groups during the last five days of the National Health Conference debated and voted for the health policies proposed by the State jurisdictions. Proposed policies receiving $70 \%$ of votes and approval by 6 of 10 discussion groups became policy. Proposals receiving $30 \%$ to $69 \%$ of votes could become policy upon receiving $50 \%$ plus one vote in a final voting round. The policies were gathered in a final report and sent to the National Health Council and to the Ministry of Health. This final document is meant to provide the basis for four years of priority setting for the Universal Health Care system in Brazil.

\section{The participants}

The participants of the $13^{\text {th }} \mathrm{CNS}$ included:

- $50 \%$ users of SUS (i.e. members of the public);

- $25 \%$ elected representatives of health professionals;

- $25 \%$ elected representatives of managers and providers of public health services.

\section{Analysis using Accountability for Reasonableness}

\section{Relevance}

The rationales for the themes and sub-themes of the $13^{\text {th }} \mathrm{CNS}$ and the decision making process to formulate those rationales were not stated in the document that set the rules for the CNS. The reports from the Municipal and State levels with the proposed health policies and the rationales for the policies were sent exclusively to the ad hoc national committee. Because the rationales were not publicly accessible it was not possible to determine whether the relevance condition had been met.

\section{Publicity}

The comprehensive document Mais Saude: Direito de Todos, describing the allocation of resources for SUS from 2008 to 2011, was made available in the Ministry of Health website (www.saude.gov.br). This document does not describe the rationales for the specific allocation of resources, nor were the rationales the subject of active public debate. Therefore, the publicity condition of Accountability for Reasonableness was not met.

\section{Appeals}

There is no appeal mechanism described in the priority setting process of the $13^{\text {th }} \mathrm{CNS}$. Although there is a clearly structured leadership, that did not in itself guarantee the participants an opportunity to appeal decisions.

\section{Enforcement}

There was no explicit mechanism to ensure that the above three conditions were met. Therefore, the enforcement condition of Accountability for Reasonableness was not met.

\section{Equity Considerations}

The number of participants per State was proportional to the State population. From the poorer Northeastern States there were 358 SUS users representing 51 million people ( 1 per 142,000), as compared to 546 participants from the most prosperous Southeastern States representing 79 million people (1 per 145,000). In the Northeast $97 \%$ of people rely exclusively on SUS for an effective representation of 1 per 137,000 users; whereas in the Southeast only $50 \%$ of people rely exclusively on SUS for an effective representation of 1 per 73,000 users.

\section{Discussion}

Health care is important in human development and societal welfare(2). In Brazil, two health care systems co-exist: the public system (Unified Health System-SUS) and the private system (Supplementary Health System-SHS). The report by the World Bank on SUS(3) highlights the lack of accountability and evidence-based planning for health policies and interventions in all jurisdiction levels. The priority setting process in the states and municipalities was considered compromised by the "lack of capacity to develop evidence-based plans to guide their [states and municipalities] health policies and interventions"(3). Those findings, in agreement with our analysis using the ethical framework Accountability for Reasonable- 
ness, suggest that the process of priority setting within SUS has not yet achieved the ethical standards of legitimacy and fairness.

The percentage of the population relying exclusively on SUS varies according to the geographic region from a low of $50 \%$ to a high of $97 \%$ (8). This means that proportional representation by population under represents users in poor areas, the reverse of what would be appropriate where equity concerns guide representation as suggested by WHO. Furthermore, the vast majority of children from 0 to 19 years of age do not have access to the Supplementary Health System(8), and there is clear evidence of unmet need of hospital care for this age group $(3,9,10)$ as well as in other countries $(11,12)$, representing a generational equity challenge and a challenge to the notion of equality of opportunities.

The priority setting process we have described and evaluated concerns exclusively the public health care system (SUS). This is an important limitation of our study. The (private) Supplementary Health System (SHS) accounts for more than $50 \%$ of health care expenditure in Brazil, although it serves less than $30 \%$ of the population(8). Evidence suggests the two systems compete unfairly for resources and, therefore, priority setting in either system will have an impact on the other $(13,14)$. Specifically, the private system will draw human resources from the public system and will not necessarily allocate according to considerations of medical need, legitimate process, or health equity(15). Accordingly, the public health system in Brazil faces an even larger challenge to meet these ethical goals.

\section{Conclusions}

According to the documents analyzed:

1. The priority setting process for SUS does not meet the ethical standards set by the four conditions of Accountability for Reasonableness;

2. People in poorer regions have less voting power in the priority setting process within the public system, as well as less access to private insurance;

3. The unmet need for hospital care for children, which reflects a remarkable inequality of opportunities for human development, may be a product of poor priority setting processes and inequity in representation.

\section{Contributors}

FFB and DKM were responsible for study design and concept development. FFB collected the data. FFB, AWH and DKM analyzed the data. FFB drafted the manuscript. AWH and DKM revised and critically edited the manuscript. All authors have red and approved the final version of this manuscript.

\section{References}

1. CSDH. Closing the gap in a generation: health equity through action on the social determinants of health. Final report of the Commission on Social Determinants of Health. Geneva: World Health Organization; 2008. Available at http://www. who.int/social_determinants/final_report/en/ (Accessed September 23, 2008)

2. Marmot M. Commission Social Determinants Hlt. Achieving health equity: from root causes to fair outcomes. The Lancet 2007; 370(9593): 1153-1163.

3. La Forgia G, Couttolenc B, Matsuda Y. Brazil Governance in Brazil's Unified Health System (SUS) Raising the Quality of Public Spending and Resource Management. 2007 (Report No. 36601-BR). Available at http://www.worldbank.org/ (Accessed May 13, 2007)

4. Daniels N, Sabin JE. Setting Limits Fairly: Learning to Share Resources for Health. 2 ed. Oxford: Oxford University Press; 2008.

5. Singer PA. Recent advances: Medical ethics. BMJ 2000; 321: 282-285.

6. Martin DK, Giacomini M, Singer PA. Fairness, accountability for reasonableness, and the views of priority setting decision-makers. Health Policy 2002; 61(3): 279-290.

7. Daniels N, Sabin J. Limits to Health Care: Fair Procedures, Democratic Deliberation, and the Legitimacy Problem for Insurers. Philosophy and Public Affairs 1997 fall; 26(4): 303-350.

8. Albuquerque C, Piovesan M, Almeida Simóes K. Caderno de Informacão da Saúde Suplementar: beneficiários, operadoras e planos. Ministerio da Saude do Brasil 2007. Available at http:// www.saude.gov.br (Accessed November 24, 2007)

9. Barbosa AP, da Cunha AJ, de Carvalho EMLA, ET al. Neonatal and pediatric intensive care in Rio de Janeiro: distribution of beds and analysis of equity. Revista da Associacao Medica Brasileira 2002 Oct-Dec; 48(4): 303-311. 
10. Victora CG, Vaughan JP, Barros FC, Silva AC, Tomasi E. Explaining trends in inequities: evidence from Brazilian child health studies. The Lancet 2000 September; 356(9235): 1093-1098.

11. Duke T, Kelly J, Weber M, et al. Hospital Care for Children in Developing Countries: Clinical Guidelines and the Need for Evidence. Journal of Tropical Pediatrics 2006; 52(1): 1-2.

12. Campbell H, Duke T, Weber M, et al. Global Initiatives for Improving Hospital Care for Children: State of the Art and Future Prospects. Pediatrics 2008; 121; e984-e992.

13. Shortell S, Kaluzny A. Organization Theory and Health Services Management. In: Essentials of Health Care Management. Delmar Publishers; 1997: 17-43.

14. Evans R. Raising the money: Options, Consequences and Objectives for Financing Health Care in Canada. Commission on the future of health care in Canada 2002; Discussion paper 27.

15. Fernandes E, Pires HM, Ignacio AAV, Sampaio LMD. An analysis of the supplementary health sector in Brazil. Health policy 2007;81 (2-3): 242-257.

Recibido: 16 de junio de 2008

Aceptado: 22 de julio de 2008 